\title{
Some uncertainties at Romanian beginning of the Philosophy of History
}

\author{
Ştefan Vlăduţescu \\ University of Craiova, 13 A. I. Cuza Street, 200585, Craiova, Romania \\ E-mail address: stefan.vladutescu@yahoo.com
}

ABSTRACT

The study is part of the contemporary effort of scanning and plimoso exploration of valuable research of the history of philosophy an philosop of history. The investigative approach proves that the Xenopolian philosophical deas extended $n$ relation to the status of philosophy at the time. It follows that in his writings th a ntist $\mathrm{philosophic}$ vocabulary and thematizes interrogatively the elevated aspects of the re nection on histor,

Keywords: history; philosophy of history; facts; events

\section{AN OUTSTANDING PHILOSOPHER FF'AD, RY}

European acknowledged $\mathrm{p}$ son ty throu $\mathrm{h}$ his original studies of history and theory of history, Alexandru D. Xenop 1847 1920) is also one of the coryphaei of the Romanian reflection on the philosopb his for history to the philosphy of history seems natural: by taking the uracy to 's scrupulosity, the historical discourse becomes the discourse of the phi ssop of histor. To the satisfaction of the Romanian philosophy of history, A. D. Xer has nisted the danger that the research exceeded partially the field within it start a in Open in elf to the ideea of history as literary genre, under the circumstanc $\mathrm{exb}$ tipg requirements to remain objective in the language undertaking, the historical disco reache historical-philosophical fission. On the other hand, out of concern for the ntific ity 8 the historical investigation, the historical discourse is impregnated by $e^{2}$ ide of the p osophy of history. Therefore, A. D. Xenopol discovers the philosophy of $\mathrm{h}$ ry In the 'g sense of the concept, A. D. Xenopol is not a philosopher of the history who doesn't realise it. 6 not a philosopher of history involuntary, he is a remarkable philosopher, one to be taken into account. Lucid mind beyond the painful experiences applied on himself, he doesn't venture into preprogrammed easy philosophical research, but he works as a philosopher with the easiness of a researcher for whom it is natural to do what he does. In his philosophical effort, Xenopol lies on the edge of the field of history, of the philosophy of history, of the philosophy of culture. 


\section{STAGES ON THE PATH OF THE XENOPOL'S REFLECTION}

a) The stage of working "on philosophical and historical ground". After 1913, writing his intelectual autobiography „The history of my ideas”, A. D. Xenopol has have a clear and balanced perspective on the path of his thinking. Then, scaning his ideational track, he reveals for us an abandonned picture of a irrepressible vocation: the theorist failed as a great philosopher of history only to become a famous historian.

Titu Maiorescu's student, closed to „Junimea”, A. D. Xenopol was a brilliant student. This made him the first scholar that "Junimea" has sent to study in Germany (1867 1871). "During my studies in Berlin, Xenopol reveals, my first Romanian publication rall o, philosophical and historical ground" (Xenopol, 1967, p. 373). Therefore, A. Y Xenopol h written on a "philosophical and historical realm" the works: "The Nation'l C, re", "T] Histories of Civilization" and "Studies on Our Present State", articles pub" shed in the iter ry Talks" magazine from 1868 until 1877. This is the sub-stage of Xenor 's ina guralphilosophical thinking. The three studies are the most valuable of $a^{1}$ tha as been fritten in all the philosophy of the Romanian history up to 1900. Xenopol a philos ar in very sense of the word and it would have been remained an outstanding a opher if hy just written this set of three studies.

Returned to the country in 1871 , as a doctor of pimsophy a 18 , he is hired as a prosecutor at the Court of Iaşi (1871-1878); subsequ ntly (1878-1883) ne has been activating as a lawyer. Alongside he was a professor of histor the Acade nic Institute, a place where he had completed his secondary education.

In this period of 12 years, interstice that we wou sub-stage of separation from philosophy and of the settlement in history, heen publishing in "Literary Talks" studies addressing philosophical-historical, cultura historm and social-economic themes. The philosophical aspects lose their first rank impo ance and decrease in scale. Are issued in turn: "Something about people's literg are 872), "I fforming our settlements" (1873), "On school education in general and espe " on he histor one" (1873), "On the epigram" (1874), "The Oath at Romanians" (1875, Hè us mation to our history" (1875), "The geographical base of the Romanian history" 76), "Our economic status" (1878), "Study of the Romanians' geograp' ca vition" $(1,2)$, "The French policy in the East".

b) The axial-histe nal stage, o e pajor studies of "pragmatic history" In 1883 he is appointed professor of Joman an history at the University of Iaşi. The history has now fully won. Following an fea worl from 1888 until 1893, his monumental "History of Romanians in Trajan Dacia" ( v volu es) has been issued in every year. The work had such a tremendous echo at ime, s ' in 1896, under the author's review, it was published in Paris, in two vg Yes, th a 100 pages: "Histoire des Roumains de la Dacie trajane". Between 1883 and 1890 -historical period of the Xenopol's intellectual life. Now the philosophical themes missing, and to the philosophical issues a minor importance is given. Over the same period, A. Xenopol has been publishing "Une énigme historique. Les roumains au moyen âge” (Paris, 1885), „Etudes historique pur le peuple roumain” (Iaşi, 1887), too. Also, generically, the publishing, between 1896 and 1912, of the "History of Romanians in Trajan Dacia" (13 volumes) belongs to this period.

c) The reflection stage on the philosophy of history.

The period of the great studies of "pragmatic history", Xenopol (Xenopol, 1967, p. 394) is followed by the theoretical reflection period of philosophy of history. Works like: "Les principes fundamentaux de l'histoire” (Paris, 1899, published in Iaşi, 1900), „La théorie de 
l'histoire (1908), „La notion de valeur en histoire” (1905)” are included here. The idea that for the status of science of history the value is a worthless criterion is compulsive for Xenopol. It induces strategic arguments unnecessary in the historical approaches, but sufficient and beneficial for the philosophical discourse. "The result of our research is the establishment of two great truths:

- that history is a science;

- that the concept of value is entirely foreign to this science and that there is no need to rely on it in order to establish it" (Xenopol, 1967, p. 322).

Therefore, the scholarly ideal of the exhaustive demonstration and the consider history apart from any axiology make the Xenopolian reflection o instant philosophical ideas. Fear of not being sufficiently well-founded argumentativer, ven wh intended purely historical, the Xenopolian discourse draws philosophical acts and $\mathrm{h}$ in demonstration activity.

What characterizes this period of meditation is the high tan of theoretic discourse, the setting of the principles of the historical study, the stabishis nd str angthening of the relation between law and series, the setting of the a outside th citeria of the historical objectivity etc. Xenopol is mobilizing now new se iolog hematicenergies. At the beginning of the twentieth century, the philosophy of hi has still itations regarding his area of research. In its turn, the conceptual language sed by A. D. Xen $\rho$ pol is one in progress of adapting and consolidation in relation to the inves gated episte nic field. Besides clarifying the epistemic object there is the development and i rovement of the scientific vocabulary. From this perspective, A. D. Xenopol may fall between who the teacher Angela Botez calls, in the book "A century of Romanian cophy", "creators of language and culture" (2005, p. 39).

In relation to the reflection stages, periods of creation have the following configuration:

d) The Xenopolian period 180083 the time during which the philosophy of history did not have a clearly define nuld vestigation, and in parallel Xenopol himself hesitated between philosophy an "tory, why "row connected on the same "realm". It follows that from the perspectiv of subsequent evolution of philosophy, Xenopol has chosen the philosophy of his $y$ initially

e) During 18 -189 the period of the pragmatic history, his writings were impregnated with philosophy ju n agh hi ory to remain pragmatic. The works produced during this period are the malmen. whig the professor Lucian Boia has included A. D. Xenopol among the grea est s, Roman Mistorians, along with Dimitrie Onciul, Ioan Bogdan, Nicolae Iorga, Con nir Giurescu/and Vasile Pârvan (2001, p. 256).

f) Bet 1896-1920, the reflective period, the theorizing of history by reasoning the developm fociety brought Xenopol at the edge of philosophy which also has a societal field of research. Initially, Xenopol and the philosophy of history have grown in parallel. Now, when Xenopol was teaching theoretically and the philosophy of history was consolidating as a science and the Xenopolian approach was intended theoretically purely historic, the discourse has resuscitated involuntary the philosophical cogitative vein. In the last part of the path of his reflection, Xenopol has reversed his interest symmetrically: if in the initial pragmatics the philosophy ranked first in the binomial philosophy-history (typically xenopolian), in the final theoretic ideas history is prevailing, without lacking blamably the philosophy of history. The "stages" defined by us find similarity with the "periods" which the well-known researcher 
Mihai Popa has set in a well documented and comprehensive study, "A. D. Xenopol philosopher of history" (2007). He has argued that in "the A. D. Xenopol's scientific activity we can distinguish three distinct periods: the period up to 1893 is the time of consecration as a historian"; between 1893 and 1899 "a necessary conversion is attained" (...) "from history to a theorist of history"; in "the third period", 1899-1920, there are "scientific achievements in both areas" and "is a deepening of the systematic outlook" (2007, p. 13).

"In addition, it is to be highlighted that a well-known contemporary of the Romanian scientist, such as Georges Palante, in "Treaty of Sociology" has remembered as revealing the thesis of philosophy of history issued by A. D. Xenopol regarding the historical of The social opposition, being an eternal and necessary social fact, falls within the de inition or laws of causality, namely the laws governing the action of the elements, of the rnal facto of the lives of societies. The facts which are the subject of this kind of lay wenop calls «the facts of repetition», namely facts that repeat constantly and rentica themselves. To these facts, in Xenopol's opinion, are opposed «tin cets or su cent), namely those which change over time due to various influences" ( anto 06, p. 12 ). Also, the elements of Xenopolian ideas are remembered by profes Gabriel s interesting even in the third millennium, as the methodological modele in arstandin and explaining the nods of "a series of succession", "characteristic of a " nof kno dge" (2010, p. 274). If the history and the inaugural philosophy make him no ceable at nation, evel, the philosophy of history and history of the third stage bring him Ev opean fame.

\section{CONCLUSION}

The path of the Xenopolian reflectio bas to, stages: the stage of the inaugural philosophy, the stage of separati om phil sophy and the settling in history, the axialhistorical stage and the stage of ne ret ction on philosophy of history. It is concluded that A.D. Xenopol is, for his tim a of history, the first Romanian with a $\mathrm{PhD}$ on the philosophy of history (The his ies of civilization").

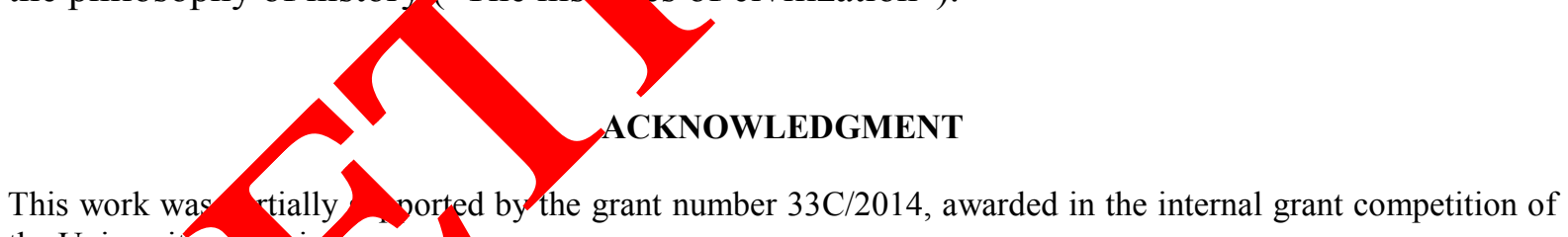
the University or ir a.

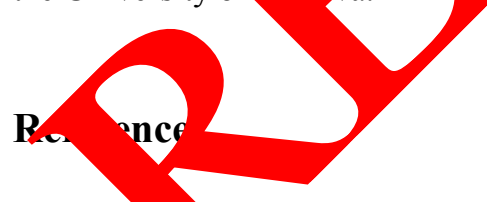

[1] L. B (2901). History and Myth in Romanian Consciousness. Budapest: Central Europe an University Press.

[2] A. Borowski, International Letters of Social and Humanistic Sciences 14 (2014) 7-17.

[3] Angela Botez (2005). Un secol de filosofie românească. Bucureşti: Editura Academiei Române.

[4] G. Palante (2006). Tratat de sociologie. Craiova: Editura Beladi. 
[5] Mihai Popa (2007). A. D. Xenopol - filosof al istoriei. Bucureşti: Editura Academiei Române.

[6] Gabriel Sebe (2010). Mass-media. Revoluţia Surselor Deschise. Geneza OSINT. In G.-C. Maior (Ed.), Un război al minţii. Bucureşti: Editura Rao.

[7] A. D. Xenopol (1967). Scrieri sociale şi filosofice. Bucureşti: Editura Ştiinţifică.

[8] Paul Dobrescu, Alina Bârgăoanu (2003). Mass media şi societatea. Editura Comunicare.ro, Bucureşti.

[9] R. Barker (2012). Social networking and identity, Chapter in: The Handbook on Technoself: Identity in a Technological Society. IGI-Global (www.igi-g bal.com/1)

[10] A. D. Xenopol (2009). Concepţia sociologică. Craiova: Editura Belar

[11] A. Borowski, International Letters of Social and Humanistic Scie ces 1) 2014) $1-168$.

[12] R. Barker, The Journal of Management and World Busine Research 1) (2009).

[13] J. MaCliam, R. Barker, Communicare 28(1) (2009).

[14] Traistaru A., Avram M. International Letters of S enomd Hum ictic Sciences 13 (2014) 79-88.

[15] Yoshimi S., Buist D., Inter-Asia Cultural Stud 4(3) (2003 433-450.

[16] Panea N. (2001). Zeii de asfalt. Antropologie a u. ulıi Bucureşti, Cartea Românească, 159-188.

[17] Karlin J. G., Journal of Japanese Studie. 28 1) (2 J2) 41-77.

[18] Dănişor D. D., Agora Intern Jon Journ Juridical Sciences 7(4) (2013).

[19] Cojocaru D., Revista de eta si Interyenţie Socială 38 (2012) 122-131.

[20] Cojocaru D., Cace S., Gavrilo i C., Journal for the Study of Religions \& Ideologies 12(34) (2013).

[21] Barker R. (201 Soci stworking and identity, Chapter in: The Handbook of Research on Technoself: Mtity in a Technological Society. IGI-Global (www glob? om/ijt).

[22] Goodwin- rey A., avey C., Progressio 22(1) (2000).

[237 Grav a J., Ko 1 M., Kot S. (2014). The role of information systems in transport giv. Interyational.

[24] A. rowski, International Letters of Social and Humanistic Sciences 14 (2014) 33-41.

[25] M. Ty, esane, Crime Research in South Africa 3(3) (2001) 8.

[26] B. Teodorescu, International Letters of Social and Humanistic Sciences 12 (2014) 73-78.

[27] Teodorescu C. N., Analele Universităţii din Craiova. Seria Ştiinţe Filologice.

Lingvistică 1-2 (2010) 190-201. 
[28] S. Sonderling (1995). Historical research in communication, in Du Plooy, G.M. (Ed) Introduction to communication, Course Book 2: Communication research. Cape Town: Juta.

[29] Bosun P., Modrak V., International Letters of Social and Humanistic Sciences 14 (2014) 66-72.

[30] W. Louw (2014). Designing Learning Experiences to Prepare Lifelong Learners for the Complexities of the Workplace. In Psycho-social Career Meta-capacities (pp. 307319). Springer International Publishing.

[31] A. Borowski, International Letters of Social and Humanistic Sciences $2(2 \circ 4)$ 110-121.

[32] Colhon M. (2009). Hierarchical Distibuted Systems Based on Sema ac Scher. 9th International Conference on Artificial Intelligence and Digita' Comn 'nicati 2009.

[33] M. Cerban, Analele Universităţii din Craiova. Seria Ştiint Filologico ingy stică 1-2 (2010) 259-264.

[34] Ioana-Narcisa Creţu (2009). Introducere în ştiinţele ysunicàn Vote de curs. Sibiu. Editura Universităţii Lucian Blaga.

[35] Marian Siminică, Aurelia Traistaru, Internatio 1 Journal of Education and Research 1(12) (2013).

[36] Bosun P., Grabara J., International Le of Socianun Humanistic Sciences 14 (2014) $59-65$.

[37] G. C. Angelopulo, R. Barker (2013). Inte ated Crganisational Communication. 2nd Edition. Cape Town: Juta

[38] S. Sonderling (1996). Kana Course Book 3: Cop mumica and the production of meaning. Cape Town: Juta.

[39] Sandu Frunză (2 1 dvertising ind Administration under the Pressure of Ethics. Les Arcs: Editions la $\mathrm{S}$

[40] P. J. Fou E (EC). (2010). edia studies: media history, media and society (Vol. 2). Juta and $\mathrm{C}$

[41] Pricecaru b 014) smart Intelligence in an Interpolar Age of Incertitude.

\footnotetext{
inte, tional.

[42」 B (ang3). Connecting to culture, Chapter in: Strategic organizational c. vunication: paradigms and paradoxes. Heinemann: Sandown.
}

[43] Y. Ko giri, K. Takanashi, M. Ishizaki, Y. Den, M. Enomoto, Procedia-Social and Behavioral Sciences 97 (2013) 422-428.

[44] Posaştiuc C. (2011). Reengineering Intelligence. Revista Română de Studii de Intelligence.

[45] N. Munteanu (2013). The Influence of Media Communication on the Military Organizations. Buletin Stiintific.

[46] Sandu Frunza, Revista de cercetare şi intervenţie socială 31 (2011) 155-171. 
[47] S. Sonderling, Communicatio 38(1) (2012) 64-83.

[48] A. Goodwin-Davey, C. Davey, Progressio 22(1) (2000).

[49] Dobrescu P., Bârgăoanu Alina (2001). Geopolitica. Facultatea de comunicare şi relaţii publice SNSPA, Bucureşti.

[50] Maior G. C. (2009). Istoricism, legalism şi teoretizare în studiul intelligence-uluieditorial. Revista Română de Studii de Intelligence.

[51] Literat I., Chen N. T. N., Communication Theory 24(1) (2014) 83-103.

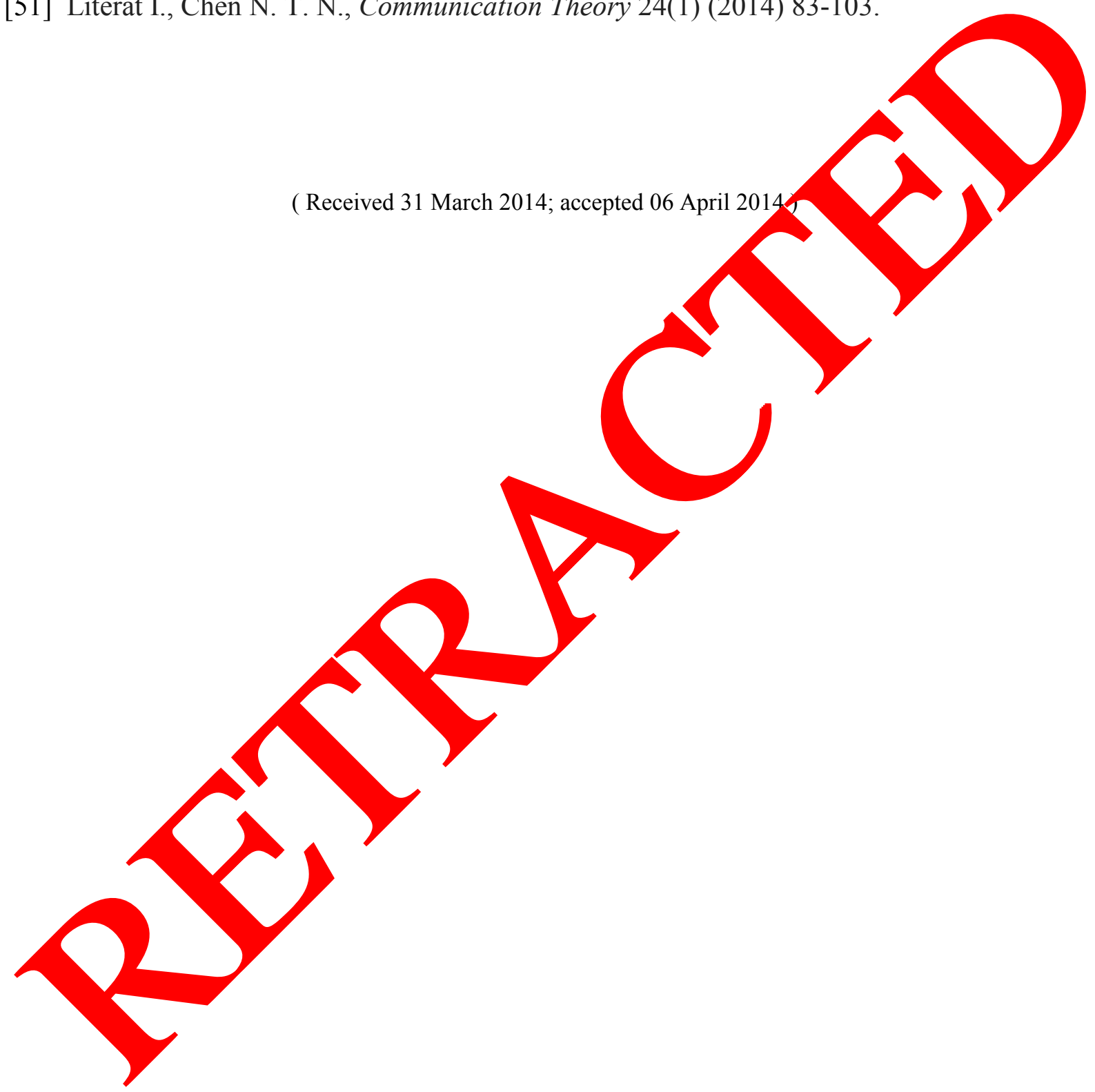

